\title{
Africanisation of Legal Education Programmes: The need for Comparative African Legal Studies
}

Journal of Asian and African Studies 2014, Vol. 49(4) 383-398 (C) The Author(s) 2013 Reprints and permissions: sagepub.co.uk/journalsPermissions.nav DOI: 10.1 177/0021909613488746 jas.sagepub.com §AGE

\section{Charles Manga Fombad}

University of Pretoria, South Africa

\begin{abstract}
Debates and discussions about the African renaissance and the Africanisation of universities have raged for decades. The goal of developing an emancipatory Afrocentric system that frees African education from the continuous and dominant influence of Euro- and American-centric cultural values remains a challenge. This is particularly so with respect to conventional African legal training and research programmes. Some African legal scholars, sometimes imbued with xenophilia, have in many ways participated in the process that has seen the continuous marginalisation of studies on the law in Africa and African law. This paper argues that there is a need to rethink the place devoted to the study of African law and African legal systems. It contends that African law generally and African legal systems specifically will hardly be able to develop when presentday students spend most of their time, especially in a course such as comparative law, studying western legal systems. In order for African legal education to be relevant and meaningful it must prepare and equip today's lawyers to operate in a global world. It is therefore suggested that an Africanised legal programme should include a course on African legal studies and aim to be contextually and globally relevant whilst being sufficiently innovative and flexible to address the urgent needs of our times.
\end{abstract}

\section{Keywords}

Africanisation, African legal education, legal systems, comparative law, Eurocentrism

\section{Introduction}

For several decades there have been wide-ranging discussions and debates about the need for an African renaissance. One stream of this debate has been advocating the Africanisation of universities on the continent. Advocates of this approach to education have been driven by the desire for an emancipatory Afrocentric system that frees African education from the continuous and dominant influence of Euro- and American-centric cultural values in favour of reclaiming African indigenous cultural values. The goal has been to enable Africa to retrieve its identity by ensuring that

\section{Corresponding author:}

Charles Manga Fombad, Professor of Law, Institute for International and Comparative Law in Africa, Faculty of Law, University of Pretoria, Private Bag X2039, Hatfield, Pretoria, 0028, South Africa.

Email: Charles.Fombad@up.ac.za 
African students are taught courses designed to enable them to better understand the continent on which they live. This should equip them with knowledge that is relevant and effective to address the diverse and complex problems the continent faces. Thus far, the numerous theories that have emerged from these discourses have hardly had any practical impact (Ki-Zerbo, 1990; Makgoba, 1999; Nkoane, 2006; Prah, 1994; Seepe, 1998). This raises questions of whether the Africanisation debate is naïve, unrealistic and futile.

The relevance of this debate has been underscored by the wave of democratisation and the contagious fever of constitutional reforms that started in Africa in the 1990s. This has coalesced with the phenomenon of globalisation, regionalisation and liberalisation that has seen the emergence of a global economy and intensified the need for strong linkages and interconnections between African states, regions and societies in order to counter the threats posed to Africa by its almost total and continuous dependence on western cultural models. One key area in which the Africanisation of university education is particularly pertinent is the teaching of law. The dramatic changes and upheavals of the recent decades have had a tremendous impact not only on the content of the laws and regulations needed to deal with these developments, but also on the way law is taught. In America, Asia and Europe, there are many indications that legal education programmes have been adjusted to prepare students for the new globalised environment (Menski, 2006; Smits, 2011). In Africa, although most of the law school programmes have also been adjusted, ${ }^{1}$ they have retained a Euro- and American- centric focus, ${ }^{2}$ which in many respects does not fully reflect the daily realities of the continent and the enormous challenges it faces in reclaiming its identity and the dominance it once had in higher education. ${ }^{3}$

One particular aspect of African legal education that has inexplicably escaped attention is the absence of specific courses devoted to the study of African legal systems. Although aspects of this are taught in some courses such as introduction to law, legal history and comparative law, and some modern textbooks (especially those on comparative law and introduction to the legal systems of the different countries) mention African law, this is often approached and treated from an essentially western prism as an incidental and unimportant issue. African legal studies in the sense canvassed in this paper are almost completely unknown. ${ }^{4}$ This ignores the fact that legal rules, unlike the physical sciences, which are governed by universal rules, are culture, context and place relative. Conventional African legal training and research are yet to fully take account of the practical needs of our environment. African legal scholars have in many respects unwittingly participated in the process that has seen the continuous marginalisation of studies on the law in Africa and African law. The failure to conduct any serious research in this area or to promote the study of modern African legal systems, combined with the continuous reliance on the readily available literature and other materials on western legal systems, has perpetuated the myth that African legal studies are irrelevant and redundant or of lesser importance. ${ }^{5}$

This paper argues that there is a need to rethink the place devoted to the study of African law and African legal systems. Research on the legal modernisation efforts within some African jurisdictions since independence suggests that some of these legal systems are developing unique features and identities that may justify them being considered as new and emerging legal systems within the family of modern legal systems (Fombad, 2010). In arguing that there is a need to put African legal studies on the legal education curriculum of African universities, in the next section, this paper will advance arguments for such a development. This will be followed by a consideration of the possible topics that such a course would cover. In conclusion, it is argued that there is no longer any rational justification for African law students who are being trained to work in Africa spending most of their time studying the law of their country or that of the European country on which their legal system is based. In so doing, they completely ignore legal developments in 
neighbouring countries with whom the country interacts at a time of increasing pressure to expand intra-African trade and cooperation.

\section{Why we need African legal studies on law programmes}

The arguments that can be canvassed in support of introducing, at best, a course devoted to African legal studies or, at worse, making this the major study component in a course such as comparative law, can be summarised under three main points. First, the need to move away from the Euro- and American-centric focus of law programmes; second, the need to reflect the changing nature of national laws; and third, as a way of reflecting the practical realities of the modern African social and economic environment.

\section{Moving away from the Euro-American centrism of African legal education programmes}

Most undergraduate students in a typical African law school will go through a programme that primarily focuses on national law. The only opportunity to go beyond national law is in those institutions where either comparative law, legal history, international law or, occasionally, private international law are taught whether as compulsory or elective courses. However, strictly speaking, it is only where comparative law and/or legal history ${ }^{6}$ are taught that the students go beyond studying national law. ${ }^{7}$ A number of significant observations can be made at this stage.

First, that there are a fair number of law schools in Africa where comparative law is either not taught or is offered only as an elective. ${ }^{8}$ In some of the institutions where it is offered as an elective, the course hardly ever attracts enough students for it to be actually taught. Second, a critical look at the course description of the comparative law courses or legal history courses in most African law schools reveals that these have been and continue to be substantially influenced by the EuroAmerican centrism that has dominated comparative law from its early beginnings, particularly after 1900 (Zweigert and Kötz, 1998: 2). ${ }^{9}$

Like most standard western textbooks that provide an introduction to comparative law, the focus of courses, besides introducing the students to the functions and methodologies of comparative law, is on the major legal systems of the world. Little attention is paid to African legal systems. More often, the little time and opportunity allocated to anything African is taken up with teaching African customary law. This reflects and reinforces the marginalisation of African legal studies manifested not only in the early textbooks but even more recent standard textbooks on introduction to comparative law. Of the two popular introductory books which are widely used in African law schools, one of them, Major Legal Systems in the World Today: An Introduction to the Comparative Study of the Law (David and Brierly, 1985), devotes a small section of part 4, entitled 'Other conceptions of law and social order', to discussing 'laws of Africa and Malagasy': 547-576. The other book, An Introduction to Comparative Law (Zweigert and Kötz, 1998), does not mention African legal systems at all. Two more recent books do the same. De Crux's 512-page Comparative Law in a Changing World (1999) devotes half a page to what he describes as 'the African situation'. The highly acclaimed and award-winning book by Glenn (2004), Legal Traditions of the World, has nothing on Africa.

It is unfortunate that the present course content of comparative law courses in many African law schools reinforces and perpetuates the myth that African law and African legal systems do not deserve anything more than a passing mention. The programme and blueprint for comparative law studies and research that have been developed in Europe and America in the last two decades often 
contain little of much relevance to the needs of comparative law students and scholars in Africa. The fact is that traditional comparative law as a university course has still not shaken off the 'civilising mission' agenda that some of the great comparatists such as R. David and Tony Jolowicz saw as its main purpose (Markesinis and Fedtke, 2009: 6). ${ }^{10}$ A number of comparatists such as Menski (2006) $)^{11}$ and Mattei (1997) have been critical of the self-conceitedness and bigotry of many western comparatists who, on the assumption of the superiority of western legal systems as the only legal models that have a universal character and content, ignore other evolving legal systems, particularly those in Africa and Asia. Many of these comparatists consider African law as irrelevant, irrational and pre-modern.

The difficulties that modern comparative law has with freeing itself from the inbuilt biases of the past are underlined by one of the most eminent and erudite contemporary comparatists, Basil Markesinis and his collaborator, Fedtke (2009:48). He not only dismisses the Eurocentrism criticism, but also questions the relevance of African law in strong derogatory language reminiscent of the colonial architects of the imposition of western laws and culture in Africa. He argues that, with the exception of South Africa, African law belongs to a 'primitive' system and should more appropriately be left to anthropologists and sociologists rather than lawyers. ${ }^{12}$ It is this mixture of bigotry and misplaced prejudice, combined with ignorance by western scholars who have refused to recognise the fact that African systems can adapt to changing circumstances and develop, which makes it imperative for African scholars to ensure that African legal developments are not sidelined by using imposed agendas from abroad. There are also some xenophilic African legal scholars who neglect or downplay African law under the misguided belief that the only way to gain recognition as a comparatist is to study and extol the virtues of western laws. For example, some of them feel that a course on Roman law is more important than one on African customary law.

The point being made here is not that western legal systems are no longer relevant or should not be studied. They are and will continue to remain, for better or worse, a permanent birthmark on our legal systems that cannot be excised. They provide the essential background against which we can study our legal developments and understand the challenges we face today. However, African legal systems and the trends and developments in them since the 1960s cannot be ignored in any modern serious scholarly work on modern comparative law. Moving away from exclusively focusing on and discussing only developments in the West gives the wrong impression that other legal systems have remained frozen in time and have nothing to offer.

An excellent example of an African legal development that shows that western models have no monopoly over how best to regulate society is the South African constitution of 1996. It would be an illusion for any serious scholarly work on comparative constitutional law today to ignore the contribution to constitutional law theory and jurisprudence that has emerged since this constitution was adopted in 1994. Again, although it is trite that the South African legal system is mixed, based on its dual Roman-Dutch and English common law heritage, it is clear from numerous studies that have been conducted that it has now mutated and developed its own distinct characteristics. This may warrant it not merely being classified as a conventional mixed jurisdiction, but also one that may soon mature into a distinct South African legal system (Fombad, 2010). These are experiences to which an African legal studies programme should draw students' attention. Comparative law must now afford fair discursive dignity to non-western legal traditions. What appears to be emerging so far is an attempt, in which many South African comparatists are complicit, to limit all discussions of African law, in a somewhat paternalistic and condescending manner, to developments in South Africa. ${ }^{13}$ They are more significant, but what is happening in other parts of Africa is equally significant and should only be ignored by those who in their indolence or bigotry still see African law as 'primitive' or supremely 
irrelevant. Besides this, the need for studying comparative law with an African focus also arises from the changing nature of national laws.

As pointed out above, there are some schools in Africa where comparative law is not taught or is merely an elective course. It is therefore not surprising that in a Nigerian study, six out of seven judges interviewed admitted that they were not aware of comparative law or had only encountered aspects of it at international conferences or in journal articles (Okeke, 2009: 35-36). It is doubtful whether a law graduate who has not studied comparative law, especially where such a graduate ends up in practice or is appointed to the bench, can perform optimally. Many well-educated lawyers have admitted that the lack of sufficient insights into legal systems other than the one in which they function places them at a disadvantage (Menski, 2006: 45). In common law countries, it is a normal practice that decided cases from other common law jurisdictions are often cited, with judges being invited to consider them in arriving at a correct decision on the basis that these decisions constitute persuasive authority. The scope for abuse and enormous damage that can be caused, especially where judges are not trained in the techniques of comparative law, are enormous and have been widely discussed in the literature of this topic (Saunders, 2006). It will therefore suffice to point out that without a sound grounding in comparative law, a judge runs the risk of misunderstanding and misapplying foreign law when called upon to do so in the normal course of adjudication. ${ }^{14}$ The need for studying comparative law with an African focus arises from the changing nature of national laws.

\section{The changing nature of national laws and the growing influence of African sources}

The contents of African legal education programmes and the way they are taught must reflect the fact that, today, unlike a few decades ago, the contents of many national laws are being influenced by legal developments in Africa itself. As a result, it no longer makes sense to design programmes that assume that most of the laws are of foreign ancestry. The progressive Africanisation of national laws is manifested in many ways.

In some areas such as constitutional law, human rights law, international law and international trade, the African Union (AU) and its predecessor, the Organisation of African Unity (OAU) have over the years adopted a number of conventions, declarations, protocols, model laws and other agreements which contain principles that have had a tremendous impact on most national laws. The main area in which this has had an impact is in constitutional law. ${ }^{15}$ An example of these are the four main instruments that make up the AU's democracy and good governance agenda, namely the principles in the Constitutive Act, the Declaration on the Framework for an AU response to unconstitutional changes of government, the declaration governing democratic elections in Africa and the declaration on election observation and monitoring. (Available at: http://www.au.int/en/treaties). The important point to note is that these instruments have laid down fundamental principles of good governance, respect for human rights, free and fair elections and transparency which member states are bound to comply with (Fombad, 2012). As with other aspects of national life governed by the AU, and increasingly also the conventions, protocols and other agreements adopted by the different regional economic communities (RECs), ${ }^{16}$ any meaningful comparative law study must necessarily consider what is happening in other African countries rather than what is obtaining in Europe. Hence a comparative constitutional law course in any African law school programme will only make sense if it involves a comparison of what the different countries on the continent are doing within the framework of the agreed standards of good governance they have committed themselves to uphold. Future lawyers and 
judges need to be taught domestic law against this background of the increasing Africanisation of national law.

Another manifestation of the progressive Africanisation of national laws is reflected in the attempts by some African countries to harmonise their business laws. The main rationale behind this is the economic argument that harmonisation of business laws will reduce the costs of doing business which are increased by the diversity in legal rules in the different countries. It is widely acknowledged that increased trade between African countries themselves is the key to unlocking the continent's economic growth potential. According to Jeremy Stevens, only about $10 \%$ of African trade is within the continent and this is the lowest level in the world. In comparison, $40 \%$ of trade in North America is within the region, while intra-regional trade in Europe stands at $60 \%$ (Bizcommunity.com, 2011). Intra-African trade has remained low despite trade reforms, better macroeconomic management, investments in infrastructure and more constructive trade partnerships.

The first major effort to pull down these barriers was made when the Organisation for the Harmonisation of Business Laws in Africa (OHADA) ${ }^{17}$ was created on 17 October 1993 in Port Louis, Mauritius. ${ }^{18}$ The organisation comprises 17 mostly Francophone countries in West and Central Africa. ${ }^{19}$ The objective of OHADA, according to article 1 of the treaty, is the "harmonisation of business laws in the contracting states by the elaboration and adoption of simple modern common rules adapted to their economies, by setting up appropriate judicial procedures, and by encouraging arbitration for the settlement of disputes. ${ }^{20}$ The scope of business laws to be covered by the Uniform Acts is defined in article 2, but the Council of Ministers is given the powers to include any other matters falling within the definition of business laws. Thus far, nine Uniform Acts have been adopted. ${ }^{21}$

Although there have been some criticisms of the OHADA system, the Uniform Acts are designed to displace and supersede the national laws of the member states on the subject concerned, and for the first time, attempt to introduce business laws adapted to the needs and circumstances of the member states (Dickerson, 2005; Kalm, 2011). For Africa to be fully integrated into the global economy and lay a solid foundation for economic recovery and growth on the continent, it needs to quickly catch up with the process of harmonisation of international business law. OHADA currently represents the best effort that has been made. Any comparative study in Africa today must necessarily take account of the tremendous changes effected by OHADA in introducing uniform and harmonised laws that apply in several African countries and lay the foundation for a possible harmonised business law regime applicable to all countries on the continent. This makes it imperative that a study of commercial law must take account of developments, especially in terms of cases decided by courts in other countries that are members of the OHADA system.

As noted earlier, a number of introductory works on comparative law, in making their passing references to Africa, usually limit their discussions to African customary law (David and Brierly, 1985). Although there are such a wondrous mosaic and diversity of customary laws, not only in Africa but within the different African countries, they have many common features. Customary courts and the informal justice system that they provide have generally been neglected. ${ }^{22}$ Yet a recent study has indicated that they constitute a "cornerstone of dispute resolution and access to justice for the majority of the populations in developing countries because they usually resolve between 80 to $90 \%$ of disputes' (Wojkowska, 2006: 5). For example, in Malawi it is estimated that between 80 and $90 \%$ of disputes are processed through customary courts, and in the case of Burundi, the figure is about $80 \%$, which go through its Bashingantahe institution as a first or sometimes only instance (Wojkowska, 2006: 5). Customary law is therefore not simply some sentimental 'primitive' relic of the past which should be of interest only to sociologists and anthropologists, 
but a living law that still has to recover from the relentless attack against it during the colonial period. ${ }^{23}$ Despite this, most African governments have in different ways perpetuated the marginalisation of customary courts that started during the colonial period. The universities have been complicit in the relegation of customary law to a subordinate position where it is either not on the law programme or merely an elective (Nicholson, 2004; Van Niekerk, 1998).

With little codification, few written records, the dearth of serious research and the passing away of many of the older generation of Africans who lived in villages and were supposed to be repositories of customary law, its future is in doubt. How can African customary law survive if it is not taught in law schools or stored in books and rests mainly in the minds of people living it in rural areas and in their daily actions, which makes research of it challenging? Furthermore, how can judges, who often deal with appeals from customary courts, properly adjudicate such matters when they were hardly taught the fundamentals of customary law in schools? And perhaps more significantly, how can customary law ever reach the global stage and attract anything more than cynical remarks from western comparatists when African scholars and legislatures on the continent sideline it. It can be argued that serious comparative studies on the operation of customary laws in the different African countries may provide the best way not only to adjust and adapt customary law to contemporary standards of justice, but more importantly, will enable experiences on how to maintain and sustain it to be shared. Customary law may be sidelined, but it will remain a vital component of a modern African legal system. Despite its defects, it cannot be wished away, but needs to be modernised.

Many recent African constitutions expressly or implicitly authorise the courts when interpreting its provisions to, inter alia, consider foreign law. This is explicitly authorised in Section 39(1)(c) of the South African constitution, 1996. It has also been persuasively argued that in interpreting the constitution, constitutional stipulations, which require the courts to promote the values which underlie an open and democratic society based on freedom and equality (see, Section 39(1)(a) of the South African Constitution, 1996 and Article 20(4) of the Kenyan Constitution, 2010) ${ }^{24}$ in an implicit manner, also allow for comparative reflections through the use of foreign laws (Markesinis and Fedtke, 2006: 26). Even if this has not been explicitly authorised, the universality of certain principles and standards, especially in the area of constitutional law and human rights, often leads counsel to cite and rely on some foreign laws to interpret national laws. In the case of South Africa, where the constitution expressly sanctions this, during its early years, the Constitutional Court relied extensively on foreign jurisprudence. Hardly any of this was from other African jurisdictions (Lollini, 2007; Udombana, 2005). So far there is little evidence of an intra-African dialogue, either in terms of cross-fertilisation, borrowing or migration of constitutional ideas from one African constitution to another or through the use by judges of jurisprudence from other African jurisdictions. Current comparative law studies on the continent and African judges continue to work under the assumption that what needs to be studied or copied can only come from the legal systems of the former colonial powers or other western systems. Unfortunately, the practice of the South African Constitutional Court may seem to perpetuate this myth. ${ }^{25}$ There might, however, be practical challenges such as knowledge of and availability of material on other African courts and the legal system within which they operate. These challenges are now being addressed.

As a result of the rapid advances in information and communication technology in the last two decades, not only judgments, but also an extraordinary amount of constitutional material from different jurisdictions, are now available. For example, access to some of the latest and most important decisions of African national constitutional courts and regional courts is merely a mouse click away. ${ }^{26}$ The benefits of this will be completely lost if African legal scholars and judges are too xenophilic, unbending and stuck in the past to see the benefits of learning from what is happening elsewhere on the continent. ${ }^{27}$ Moreover, as noted earlier, the progressive nature of the 1996 South 
African constitution and high quality of the judgments delivered by its Constitutional Court, which in certain areas of the law (such as socio-economic rights) has laid down principles that are copied the world over, suggests that we do not need to continue to look out of the continent for and copy western constitutional models. We can only become aware of these developments if there is a dedicated course on African legal systems. However, there are also several practical imperatives for the introduction of such a course.

\section{Practical African realities}

A number of practical imperatives compel a rethinking and refocusing of African legal education in general and comparative law in particular in order to rid it of its present western bias in focus, orientation and content, and the misconceived notion that African legal developments are an irrelevance that deserves nothing but passing mention. A new kind of comparative law programme that reflects and responds to Africa's peculiar challenges and its practical needs and realities is needed. In this regard, four important points need to be noted.

The first is the practical reality resulting from the similarity of the experiences that African countries have gone through from colonialism and its aftermath to the challenges of dealing with ethnic, cultural and religious diversity, which means that they can learn from each other's experiences. This does not mean that they should blindly copy from each other but that they can learn invaluable lessons and draw inspiration from their dynamic and rich jurisprudence. Legal systems continue to innovate, experiment and adopt new solutions to the new problems that arise each day and from which others can learn. The socio-economic and political conditions as well as the general context in which African countries operate are so similar that a solution adopted to address certain legal problems in one African country is more likely to be successful in solving similar problems in another African country than solutions imported from abroad.

The second point has to do with the forces of globalisation which appear to have unleashed the prospects of "nothing short of a cultural bombardment on the developing countries by western modernity - capitalism, industrialism and the nation-state system' (Doshi, 2003: 352), or, in the words of Menski (2006: 37), a 'remodelled version of earlier colonial domination, now in the garb of attractive trade deals and development programmes'. He goes further to point out that 'much of the current debate on globalisation seems still inspired by the theme of "civilising mission," now in the name of universalism and human rights' (Menski, 2006: 11). Nevertheless, the optimistic theme of his book is that globalisation is much more than a single phenomenon and is not actually moving the world in the direction of uniformity. This is certainly an argument made more in hope and expectation than as a reflection of practical reality. ${ }^{28}$ For, as he correctly adds, 'if globalisation means increasing hybridisation in locality-coloured and culture-specific forms worldwide, rather than uniformising homogenisation, lawyers need to be better equipped to understand the manifold pluralities within and between legal systems as complex entities with ragged boundaries' (Markesinis and Fedtke, 2009: 25). The only way that African and other non-western legal cultures can cope with the spreading wings of globalisation is not to resist it but rather to assert themselves from within it. This will require the active participation of a new generation of African scholars imbued with knowledge of legal developments in Africa and ready to take on and influence global legal developments. Although this is a process which requires an overall overhaul of the Euro- and American-centric approach to comparative law, a better understanding and acceptance of diversity and recognition of the potential role of African law in general can only start when African scholars as well as its legislatures and judges take the lead. All or most of the arguments that can be made in favour of studying western legal systems to enable students to gain at an early stage of their legal 
education an awareness that problems can be solved by different answers and also that a global legal perspective in today's global village is necessary, can be made with even more force for studying other African legal systems. It is ultimately a question of adapting to a new and fastchanging world - a world in which, unlike in the past, African law and African legal principles must be taken into account in shaping the future direction of global legal developments.

Finally, the multiplication of legal sources through the processes of Africanisation and internationalisation of national law must logically be reflected in legal scholarship. Comparative law in most African countries, with perhaps the exception of South Africa, is still being taught from western textbooks. Refocusing the comparative law course with an emphasis on African legal studies would certainly encourage more research and publications on African law. In this way, academics could actively promote the use of foreign law from other African jurisdictions. However, the success of this will depend on how the restructuring of the law programme is approached and the scope it allows for the study of African law. This raises a vital question that we will now turn to.

\section{What should the scope of the African legal studies programme cover?}

Generally, law schools should not merely be a place where students are taught about the law as it is found in legislation and court decisions. An effective law programme should teach students about the past, the present, and importantly, try to anticipate the future and prepare them for it. Put differently, relevant and effective legal education cannot be isolated from the history of the country and its present and future challenges.

It is from this premise that it is argued that in today's globalising world, it is unrealistic to teach students only national law at a time when interaction with foreign laws is not only unavoidable but a necessary part of daily life. It is the main contention in this paper that a crucial step in preparing African law students for global citizenship will be to afford them an opportunity to know more about what is happening in their immediate surroundings. Comparative law courses that are supposed to introduce them to foreign laws have unfortunately focused almost exclusively on western laws. The effect of this is that law graduates tend to know the basics of European legal systems and hardly anything about the African legal systems that surround them and with which they are increasingly coming into contact each day as efforts towards regional integration intensify. It is this trend that must be reversed through the introduction of either a separate course or a section in the comparative law course devoted to the study of African legal systems. In this way, law schools can also play a decisive role in shaping the law of the future. It is also worth noting that anecdotal evidence and the evidence from examining many law school programmes suggest that not only do most postgraduate law programmes have a comparative law focus but also most of the topics chosen for dissertations and theses are comparative in nature. It is therefore clear that many African law schools do a lot of comparative legal research but often without either the knowledge and skills on the proper techniques and methodologies to use, or more seriously, without any focus on practical African needs and realities.

Beyond the point that it is now imperative to include African legal studies on law programmes, it is difficult to be prescriptive as to what exactly they should contain. Nevertheless, it is necessary to ensure that there is a proper balance between what was studied in the past and what needs to be introduced and added to the particular course. It will inevitably mean that some aspects or parts of the old programme have to be eliminated or summarised to make way for what will be introduced. There are sufficient differences in the sources of laws in the different countries and the weight given to each of these to suggest that each law institution has to look at its particular situation to determine how it will go about this. Mindful of the fact that there is often pressure on curriculum 
designers to include what may perhaps be considered as more exotic courses that seek to address more visible problems, such as the environment, trade and terrorism, combined with the fact there aren't many law academics who have specialised or developed a research interest in comparative law, a number options need to be considered. These are as follows:

a) Comparative law should be made a core course in every law school; or

b) it should be made an elective course, and in this case, it should:

c) be complemented by introducing comparative law in other courses such as legal history, introduction to law, etc.; and

d) elements of comparative law and methodologies should be infused and streamlined into other law courses.

Whichever option is chosen, the critical factor is the place devoted to African legal studies. Ways in which African legal studies or an African focus could be infused into the programme will differ according to whether it is a programme at the undergraduate or postgraduate level.

For a course at the undergraduate level, it is suggested that a course with an African focus should include the following:

1. A study of the major legal traditions in the world today. This should include Chinese law, on account of the growing importance of Sino-African trade.

2. A study of the evolution of the received legal systems in Africa. The structure and content of African legal systems will need to be examined, and the basic concepts of African legal theory and practice that have emerged will need to be discussed. Legal history should no longer be simply a study of the history of western legal systems with African developments mentioned only in passing. It should be given as much weight and importance as the history of western legal systems. This should cover topics such as:

a) Common law in Africa;

b) Civil law in Africa;

c) Legal pluralism: This should include aspects of customary law and religious laws in Africa and their interaction with each other as well as their interaction with the received legal systems. This should be done from a comparative perspective. Taking African customary law as an example, the tensions between many African customary law rules and principles and modern human rights and constitutional law principles in areas such as marriage, inheritance, succession and land tenure are well known. These problems cannot be wished away simply by ignoring them or pretending that they do not matter, given the significance of customary law courts in resolving disputes in Africa. Some African countries have adopted imaginative ways of dealing with some of these conflicts. ${ }^{29}$ Innovative solutions to problems that affect many other African countries developed in one country could, with slight adjustments, be adopted and applied in other countries. This, however, can only happen if there is knowledge about these developments, and such knowledge can only be gained if African scholars and students are afforded opportunities to learn about how customary law is applied in other African countries.

3. Constitutionalism in Africa is another important topic. It is necessary in a comparative law course or an African legal studies course to briefly discuss the attempts being made by African countries to establish and entrench constitutional democracy based on the principles of constitutionalism, good governance and respect for the rule of law. 
4. Transnational business law, using OHADA as an example, is also a topic which needs to be studied in African law schools.

As regards the postgraduate level, there are two possibilities. First, there could be a specialised course in comparative African law. This could include dedicated courses such as:

a) Comparative law theories and methodologies;

b) Comparative legal systems;

c) African comparative law;

d) Legal pluralism in Africa.

Second, the specialisation in different courses could be infused with a comparative focus on Africa. The specialised courses could include the following:

a) Comparative family law;

b) Comparative constitutional law;

c) Comparative religious laws;

d) Comparative criminal law;

e) Comparative tax law etc.

This approach essentially calls for a new kind of comparative law in African law schools.

\section{Conclusion}

The study of law in African law schools should no longer be confined to merely a simple exercise in which students are taught to uncritically accept and learn how to apply national laws, most of which are based almost exclusively on inherited colonial laws with their built-in western bias. Law and legal rules will be meaningless if they do not address the real needs, concerns and fears of the people. In spite of the strong winds of globalisation which necessitate the adoption of uniform or harmonised laws, the development options for Africa and the forces for strengthening regional integration and hence intra-African cooperation and development are being felt. One of the primary ways of enhancing intra-African cooperation, it is argued, is by encouraging African law schools to adopt programmes that include African legal studies.

This paper argues that African law generally and African legal systems specifically will hardly be able to develop when present-day students spend most of their time, especially in a course such as comparative constitutional law, studying western legal systems and have only limited knowledge of their own legal system and even less knowledge about the legal systems of the neighbouring countries with which they interact daily.

Legal education does not occur in a value- and context-neutral environment. It must reflect the needs of the environment and the living experience of the people. In order for African legal education to be relevant and meaningful it must prepare and equip today's lawyers to operate in a global world. This must be done within the framework of balanced programmes in which students learn about African law and have some knowledge of African legal systems, current developments and emerging theories and principles from African scholars. This contextualised vision of today's reality is vital because globalisation does not necessarily mean 'uniformising homogenisation' but rather 'increasing hybridisation in locality-coloured and culture-specific forms worldwide' (Menski, 2006: 25). 
Africa can only contribute towards this plurality-conscious change, especially in the study of comparative law, if it designs programmes that promote more research into and teaching of African legal systems. In this regard it can be argued that law schools should not merely focus on teaching the law as it is, but should also try to anticipate and shape the law of the future by the imaginative design of their programmes. The ultimate goal is to provide a platform for legal research and thinking which encourages African scholars, students and judges to develop the ability, mind-set and confidence to look at the jurisprudence and laws of their neighbours for possible solutions to legal problems in their own country. At a time of rapid changes, increasing globalisation and regionalisation, a purely national perception of the law or legal education is no longer sustainable. An Africanised programme that includes a course on African legal studies should aim to be contextually and globally relevant as well as being sufficiently innovative and flexible to address the urgent needs of our times.

\section{Acknowledgement}

This paper is based upon a paper presented at the Comparative Law in Africa Methodology Workshop at the Centre for Comparative Law in Africa (CCLA), Faculty of Law, University of Cape Town, 22-24 October 2012.

\section{Funding}

The research for this paper and participation at the conference where it was presented was made possible by incentive funding from the South African National Research Foundation.

\section{Notes}

1. The most 'significant' of these changes have taken place in South Africa with the recurriculisation of the LL.B degree in 1997 after the end of apartheid in 1994. Yet South Africa still grapples with the challenges of how far it should go in Africanising its programmes, with debates such as those on whether or not Roman law, which is no longer taught as a course in many European universities or only offered as an elective, should be retained. See, for example, Nicholson, (2011: 101-114).

2. At independence, most African countries inherited the legal systems imposed during the colonial period. The basic structure and framework of pre- but mostly post-independence legal education programmes were based essentially on the imposed foreign laws and for the most part have retained this characteristic up to the present.

3. See Naudé (2011), who reminds us of how Africa was once dominant in higher education with the brilliant School of Alexandria and the excellence of Egyptian engineering and Zimbabwean building projects.

4. It is somewhat ironic that something close to this is taught, not in Africa, but rather in the American University's Washington College of Law, in a course entitled 'African law: Selected topics,' which was scheduled to be taught by Professor Andrew Novak in autumn 2012. Thus far, it provides the best example of a commendable attempt to introduce students to African law and its developments over the years. See http://www.wcl.american.edu/registrar/coursesapp/inf_course.cfm?number=LAW-795J001\&time=fall_2012 (accessed on 20 October 2012).

5. In fact, Joireman (2001: 577) has suggested that the courts and legal systems in most countries became even closer to the metropolitan system after independence than they had been during the colonial days. The elites preferred to continue with the familiar system they had inherited rather than construct something new.

6. In some law schools, legal history is taught with aspects of comparative law covered in it (see, for example, the law department of the University of Botswana), and this is probably true of many South African law schools. For a more detailed analysis of the exact situation in South African law schools, see Nicholson (2011: 104-105) at note 18.

7. However, it should be pointed out that in some institutions, the study of foreign legal systems is taught as 
part of a module such as the course 'Introduction to law and legal systems' taught in the law department of the University of Buea and the English private law department of the University of Yaoundé II Soa.

8. For details of the situation in South African law schools, see Nicholson (2011: 104-105) at note 18. It is not offered in the University of Kenyatta law school in Kenya, but interestingly, it is offered at postgraduate level on various comparative law courses. These are comparative law of evidence, comparative criminal law, comparative environmental law, comparative jurisprudence, comparative constitutional law and comparative maritime law. Unfortunately, it was not possible to obtain any information on the situation in other African law schools, either because they have no website, or if they did, this did not provide any information either on the law courses taught or their content.

9. The Congress of Paris of 1900 is where comparative law in its present form was formally launched.

10. This fitted in rather neatly with the colonial era philosophy wherein laws were imposed on the colonial territories as part of the mission to 'civilise' them. See Conklin (1997).

11. Menski articulates a critical rethinking of the study of comparative law and legal theory and highlights the inadequacies of the current western theoretical approaches.

12. In Engaging with Foreign Law (Markesinis and Fedtke, 2009: 48), the learned authors of this book in expressing their views about non-western laws state the following: "For we are not just advised to read the extra book or article about the laws and customs of such "less developed" systems. We are asked to try and immerse ourselves in completely different legal cultures in order to understand them and learn from them. Is our life span so long and are our library resources so unlimited to allow us the luxury suddenly to shift direction and start studying, say, African law, Native American law, or religious law as a first priority?' If authors of such repute can express such absurd and archaic views about African law, in spite of the fact that one of the authors was born in Tanzania and studied and worked in South Africa, it only goes to support the anti-non-western and probably racist mould of conventional comparative law.

13. Even the Washington College of Law's 'African law: Selected topics' syllabus devotes one of its 14 topics to a study of the 'South African Law and Legal System'. See http://www.wcl.american.edu/registrar/ coursesapp/inf_course.cfm?number=LAW-795J-001\&time=fall_2012 (accessed on 20 October 2012).

14. The following are some of the main instances in which a judge may be obliged to look at foreign law: a) where local law has gaps, is ambiguous or is in obvious need of modernisation; $b$ ) where the problem faced has been encountered in other legal systems and it is desirable to adopt a harmonisation response; c) where foreign law provides additional evidence to support the proposed solution; d) where the law being interpreted comes from another legal system; and e) when a judge is confronted with a law regulating a highly technical matter rather than a value-laden issue. See Markesinis and Fedtke (2006).

15. It might at first blush appear as if the Africanisation process is limited mainly to the area of public law. This is in sharp contrast to developments in Europe. The reality, however, is that since the constitutional reforms of the 1990s, many areas of private law are now regulated via constitutional law principles. This constitutionalisation of private law is evident in certain parts of the law like delict (in an area such as the law of privacy, right to dignity, etc.), property law (constitutional property law rights and family law (right of equality)). This is highly developed in South Africa. A leading example of this is Van der Walt (2011).

16. The AU has officially recognised eight of these, namely CEN-SAD (the Community of Sahel-Saharan States), the Common Market for Eastern and Southern Africa (COMESA), the East African Community (EAC), the Economic Community of West African States (ECOWAS), the Economic Community of Central African States (ECCAS), the Intergovernmental Authority for Development (IGAD), the Southern African Development Community (SADC) and the Union du Magreb Arabe (UMA).

17. OHADA is the French acronym by which it is better known. It stands for 'Organisation pour l'Harmonisation en Afrique du Droit des Affaires'.

18. The treaty entered into force on 18 September 1995 after receiving the minimum number of ratifications required for its entry into force.

19. The other countries are Benin, Burkina Faso, Central African Republic, Chad, Congo, Ivory Coast, Gabon, Guinea, Mali, Mauritius, Niger, Senegal and Togo. The latest member of OHADA is DR Congo, where the OHADA regime took effect from 12 September 2012.

20. Unless otherwise indicated, all quotations from the OHADA treaty or its Uniform Acts are taken from the 
official translations of the original texts available at the English site, http://www.ohadalegis.com/anglais/ about_ohada.htm.

21. However, Kalm (2011: 2) suggests that there are now 10 Uniform Acts, but no evidence of this could be found either at the OHADA website or that of the supporters' group, Association pour L'unification de Droit en Afrique (UNIDA). This is not surprising because both websites are hopelessly outdated in many respects.

22. Very little of most national budgets for the judiciary are allocated to traditional courts. See further, Charles Manga Fombad, 'The context of justice in Africa: Emerging trends and prospects' (a UNDP Report) (forthcoming).

23. Taylor, in 'Indigenisation and Africanisation', observes about South Africa (the same observation is true of other African countries) that, throughout its history, 'an indeterminably large amount of money was put to marginalising indigenous knowledge and promoting western knowledge.' See http://www.cepd. org.za/?q=node/143 (accessed on 7 October 2012).

24. For a reliance on this provision in the South African constitution, see Ferreira v Levin NO and Others 1996 (1) BCLR 1.

25. Anecdotal evidence suggests that some Anglophone African courts have occasionally referred to decisions of the South African Constitutional Court, but the reverse has hardly ever happened. It is also noted that there is hardly any cross-referral between Francophone and Anglophone African courts.

26. The Southern African Legal Information Institute (SAFLII) now provides free online access to the latest decisions from the superior courts in most SADC countries. See http://www.saflii.org/.

27. It is true that, epistemologically, Francophone and civil law judges, especially where there is no express constitutional authorisation to that effect, do not have the flexibility that Anglophone judges have in resorting to foreign law because the legislature tries to be as comprehensive and exhaustive as possible in drafting statutes. Nevertheless, many recent studies suggest that this is changing. (Markesinis and Fedtke, 2006: 64-66; Smits, 2004).

28. In fact, Markesinis and Fedtke (2009: 4) note that surviving the globalisation phenomenon is one of the challenges that modern comparative law faces. This should not be a problem if modern comparative law and globalisation wake up to the need for recognising and accepting as a practical fact of life a world in which the diverse legal systems must co-exist harmoniously and with mutual respect.

29. For two contrasting but imaginative and progressive examples, see the Benin Constitutional Court Decision DCC 02-144 of 23 December 2002 and that of the South African Constitutional Court in Bhe v Magistrate of Khayelitsha 2004 (2) SA 544 (C).

\section{References}

Bizcommunity.com (2011) Africa must do business with itself - Standard Bank economist. Available at: http://www.bizcommunity.com/Article/410/87/61613.html (accessed 8 October 2012).

Conklin A (1997) A Mission to Civilize: The Republican Idea of Empire in France and West Africa 18951930. California: Stanford University Press.

David R and Brierly J (1985) Major Legal Systems in the World Today: An Introduction to the Comparative Study of the Law, $3^{\text {rd }}$ ed. London: Stevens \& Sons.

De Crux P (1999) Comparative Law in a Changing World, $2^{\text {nd }} e d$. London: Cavendish Publishing Ltd.

Dickerson CM (2005) Harmonizing business laws in Africa: OHADA calls the tune. Columbia Journal of Transnational Law 44(1): 17-73.

Doshi SL (2003) Modernity, Postmodernity and Neo-sociological Theories. Rawat: Jaipur.

Fombad CM (2010) Mixed systems in Southern Africa: Divergences and convergences. Tulane European \& Civil Law Forum 25: 1-21.

Fombad CM (2012) The African Union and democratization. In: Haynes J (ed) Routledge Handbook of Democratization. London: Routledge, pp. 322-336.

Glenn P (2004) Legal Traditions of the World, $2^{\text {nd }} e d$. Oxford: Oxford University Press.

Joireman SF (2001) Inherited legal systems and effective rule of law: Africa and the colonial legacy. Journal of Modern African Studies 39(4): 571-596.

Kalm G (2011) Building legal certainty through international law: OHADA law in Cameroon. Buffett Center for International and Comparative Studies Working Paper Series. Working Paper No. 11-005. Available 
at: http://www.cics.northwestern.edu/documents/workingpapers/Buffett_11-005_Kalm.pdf (accessed 9 October 2012).

Kenyan Constitution of 2010. Available at: http://www.kenyaembassy.com/pdfs/The\%20Constitution\%20 of $\% 20$ Kenya.pdf

Ki-Zerbo J (1990) Educate or Perish: Africa's Impasse and Prospects. Dakar: Breda UNESCO-UNICEF.

Lollini A (2007) Legal argumentation based on foreign law: An example from case law of the South African Constitutional Court. Utrecht Law Review 3(1): 60-74.

Makgoba NW (ed) (1999) African Renaissance: The New Struggle. Cape Town: Mafube Publishing.

Markesinis B and Fedtke J (2006) Judicial Recourse to Foreign Law: A New Source of Inspiration? Abingdon: UCL Press.

Markesinis B and Fedtke J (2009) Engaging with Foreign Law. Oxford: Hart Publishing.

Mattei U (1997) Three patterns of law: Taxonomy and change in the world's legal systems. American Journal of Comparative Law 45: 5-44.

Menski W (2006) Comparative Law in a Global Context. The Legal Systems of Asia and Africa, $2^{\text {nd }}$ ed. Cambridge: Cambridge University Press.

Naudé P (2011) Africanising higher education. Available at: http://www.businesslive.co.za/ (accessed 9 October 2012).

Nicholson C (2004) The challenges of teaching legal history to a demographically diverse and educationally under-prepared student body. Murdoch University Electronic Journal of Law 11(4).

Nicholson C (2011) The relevance of the past in preparing for the future: A case for Roman law and legal history. Fundamina 17(2): 101-114.

Nkoane MM (2006) The Africanisation of the university in Africa. Alternation 13(1): 49-69.

Okeke C (2009) African Law in Comparative Law: Does Comparativism have Worth? Available at: http://works. bepress.com/cgi/viewcontent.cgi?article=1000\&context=christian_okeke (2009, accessed 15 October 2012).

Prah KK (1994) Perceptions of 'Africanisation' or 'endogenisation' at African universities: Issues and recommendations. Journal of African Universities in the Twenty First Century 2: 321-340.

Saunders C (2006) The use and misuse of comparative constitutional law. Indiana Journal of Global Legal Studies 13(1): 37-76.

Seepe S (ed) (1998) Black Perspectives on Tertiary Institutional Transformation. Thohoyandou: Vivilia Publishers and University of Venda.

Smits JS (2004) The Europeanisation of national legal systems: Some consequences of legal thinking in civil law countries. In: Van Hoecke M (ed) Epistemology and Methodology of Comparative Law. Oxford: Hart Publishing, pp. 229-245.

Smits JM (2011) European legal education, or: How to prepare students for global citizenship? The Law Teacher 45(2): 163-180.

South African Constitution of 1996. Available at: http://www.info.gov.za/documents/constitution/1996/a108-96.pdf

Udombana NJ (2005) Interpreting rights globally: Courts and constitutional rights in emerging democracies. African Human Rights Law Journal 5: 47-69.

Van der Walt AJ (2011) Constitutional Property Law, $3^{\text {rd }}$ ed. Cape Town: Juta \& Co.

Van Niekerk G (1998) A common law for Southern Africa: Roman law or indigenous African law. CILSA 31: $158-173$.

Wojkowska E (2006) Doing Justice: How Informal Justice Systems can Contribute. United Nations Development Programme. Oslo Governance Centre. Available at: http://www.democraciaejustica.org/cienciapolitica3/sites/default/files/doingjusticeewawojkowska130307.pdf (accessed 8 October 2012).

Zweigert K and Kötz H (1998) An Introduction to Comparative Law, $3^{\text {rd }}$ ed. Oxford: Clarendon Press.

\section{References: Cases}

Benin Constitutional Court Decision DCC 02-144 of 23 December 2002.

Bhe v Magistrate of Khayelitsha 2004 (2) SA 544 (C).

Ferreira $v$ Levin NO and Others 1996 (1) BCLR 1. 


\section{Author biography}

Charles Manga Fombad is the Head of the African Constitutional Law Unit at the Institute for International and Comparative Law in Africa, Faculty of Law, University of Pretoria. He is the author/editor of 8 books and has published more than 60 articles in local and international peer reviewed journals, more than two dozen book chapters as well as numerous other publications and conference papers. He is also a member of the editorial board of several international Journals and a member of several professional associations. 